\title{
Geo-environmental improvement of sediment by using microbial fuel cell (MFC)
}

\author{
M. Azizul Moqsud ${ }^{\text {i) }}$ and Yuichiro Kanehagi ii)
}

i) Associate Professor, Department of Civil Engineering, Yamaguchi University, Ube shi, 755-8611, Japan.

ii) M.Sc. Engineering student, Department of Civil Engineering, Yamaguchi University, Ube shi, 755-8611, Japan.

\begin{abstract}
In this study, a microbial fuel cell has been designed for the marine sediment to generate bio-electricity and to improve the geo-environmental condition simultaneously. Four different kinds of sediments were used in the laboratory tests to generate the bio-electricity. The acid volatile sulfide (AVS) was measured to verify the improvement of the geo-environment of the marine sediment. The effects of temperature, number of anode and the different conditions of the circuit were evaluated to observe the bio-electricity generation. The amount of voltage value showed almost twice when two anodes were used compared with single anode. Higher temperature showed the higher voltage due to enhanced activity of the bacteria in the higher temperature. Acid volatile sulfide values reduced quickly when the circuit was completed. All the samples showed the decreasing trend of AVS value with time and reached at the $0.2 \mathrm{mg} / \mathrm{g}$ dry mud indicating the geo-environmental improvement of the marine sediments.
\end{abstract}

Keywords: geo-environmental engineering, microbial fuel cell, sediment improvement, acid volatile sulfide, carbon fiber

\section{INTRODUCTION}

Microbial fuel cells (MFCs) are bio-electrochemical transducers that convert microbial reducing power (generated by the metabolism of organic substrates) into electrical energy (Allen et al., 1993; Bennetto HP., 1984; Habermann W, and Pommer E-H. 1991, Logan and Regan, 2006; Hong et al. 2009; Spiegel and Preston, 2003, Stirling et al. 1983, Suzuki et al. 1978, Tsujimura at al. 2001). The scarcity of electricity is one of the major hindrances for the development of many countries all over the world. Many developing countries can produce electricity to supply only half of their demand. So power shortage and load-shedding are very common phenomena which cause serious problems for

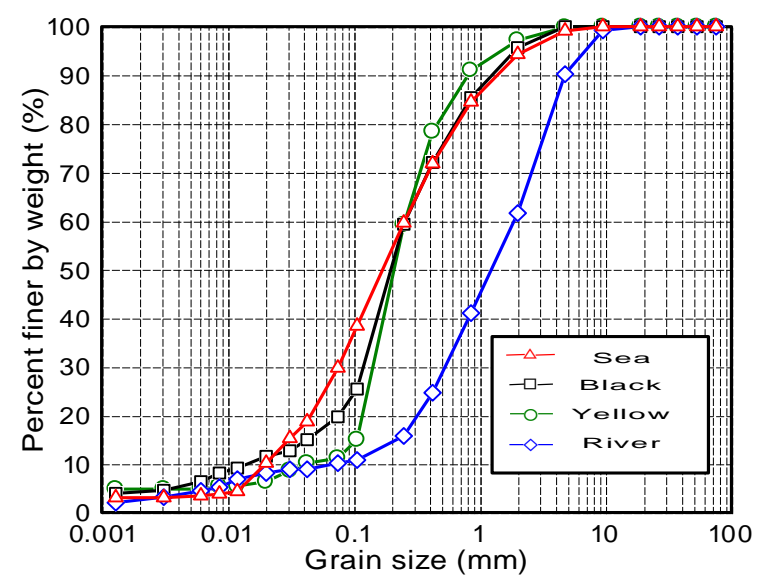

Fig.1. Grain size distribution of sediments

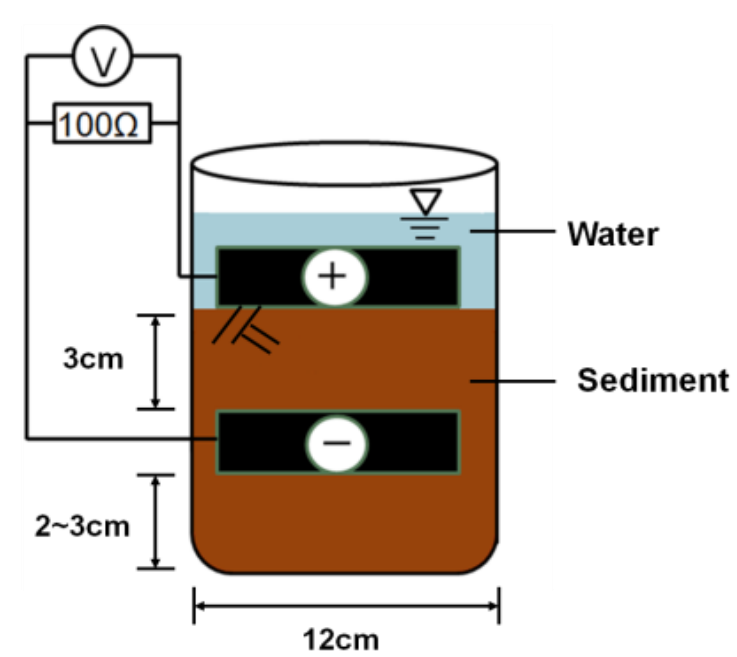

Fig. 2. Schematic diagram of SMFC in the laboratory

the population of the developing countries, especially during the night time. Renewable bio-energy is viewed as one of the ways to alleviate fuel needs of the future and to overcome the crisis of global warming (Logan 2007). In this way, bioelectricity production employing microbial fuel cell (MFC) has generated considerable interest in both basic and applied research in recent years (Moqsud, et al. 2013).

In this study, an attempt has been taken to generate bio-electricity which is both green and safe by using marine sediment in microbial fuel cell method and at the same time the geo-environmental conditions of the 
marine sediments will be improved by MFC technology.

\section{SAMPLE COLLECTIONS}

Marine sediments were collected from the sea near the Yamaguchi city, Yamaguchi prefecture, Japan. The sediments were named as sea sediment, black sediment, Yellow sediment and another one is from river sediment. Figure 1 illustrates the grain size analysis of the four sediments. It is seen that all the three marine sediments showed the similar trend and which are differed from the river sediment.

AVS is a natural agent in sediments which complexes some cationic metals and thereby influences the toxicity of these metals to benthic organisms. Because of its influence on metal bioavailability, AVS has been proposed as a key normalization phase for the development of sediment quality criteria for metals. In this study, the AVS value will be taken as a key indicator to the geo-environmental conditions improvement. According to the Japanese fisheries research association, the safe value for AVS is $0.2 \mathrm{mg} / \mathrm{g}$ dry mud for the benthos living in the mud.

\section{METHODS AND MATERIALS}

Figure 2 illustrates the laboratory test set up for the microbial fuel cell. One liter glass beaker was used in the laboratory as a sediment microbial fuel cell. The sample was placed in the cell. Carbon fiber (Toray corp. Tokyo) was used for both the anode and cathode (Moqsud and Omine, 2010, Omine 2009). The anode was placed inside the sediment and the cathode was placed on the top. Both of the electrodes were connected to a data logger (Midilogger GL200, Graphtec, Japan) and a fixed external resistance (100 $\Omega$ ). The external resistance was fixed at $100 \Omega$ by assessing the polarization curve with different resistors

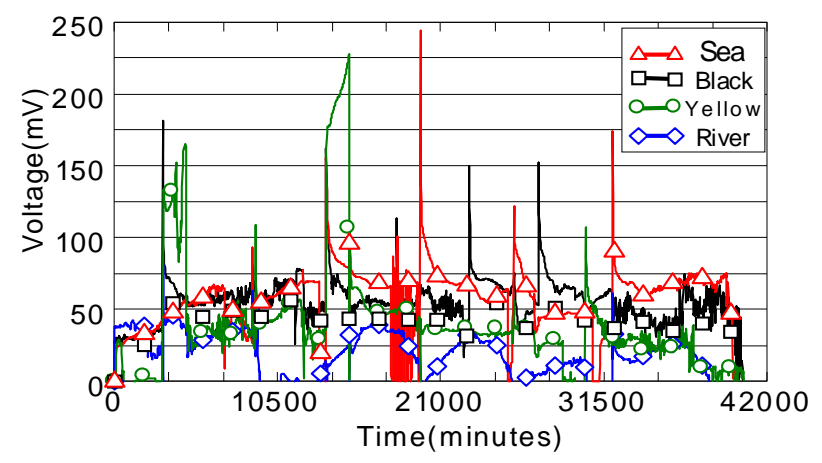

Fig. 3 Variation of voltage with time and also by comparing open circuit voltage (OCV). The data logger was set to measure the voltage and temperature data at 20 minute intervals. The stored data was collected by the data logger and analyzed some days. The laboratory investigation was conducted in a constant room temperature of $25^{\circ} \mathrm{C}$ (Moqsud et al. 2014).

\section{RESULTS AND DISCUSSIONS}

Figure 3 illustrates that the variation of voltage with time. It is seen that the marine sediments showed the higher value of voltage than the river sediments.

Figure 4 illustrates the effects of the anode number in the sediment microbial fuel cell. It is seen that the amount of voltage has shown twice when the anode number was double. The peak reached upto $500 \mathrm{mV}$. The electron acceptor areas were increased by increased the number of anode as a result the peak value was also showed higher when double anode was used instead of single anode.

Figure 5 illustrates the effects of temperature on the voltage generation. It is seen that when the temperature was 25 degree Celsius then the amount of voltage was also higher compared to the MFC at 5 degree Celsius. The bacterial activities increased in the increased temperature (Rabey et al. 2004; Park et al. 2003).

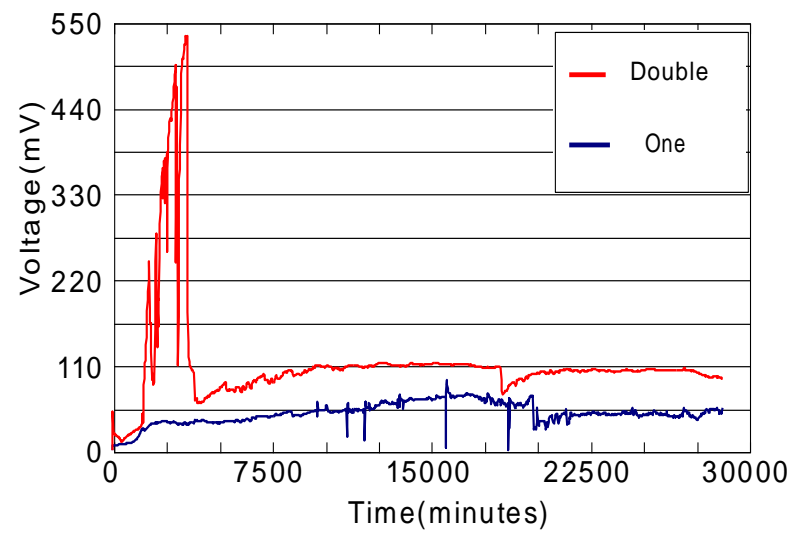

Fig. 4. Effects of single anode and double anode

Figure 6 illustrates the variation of AVS with time in different circuit condition and compared with the sediment without electrode materials. It was seen that when the circuit is completed then the AVS value reduction was faster with compared with control sediment (without electrodes). The AVS values indicated that the geo-environmental conditions improved with the time. The control sediment (without electrodes) was slower than the sediment MFC.

Figure 7 illustrates that the AVS value varied with time 


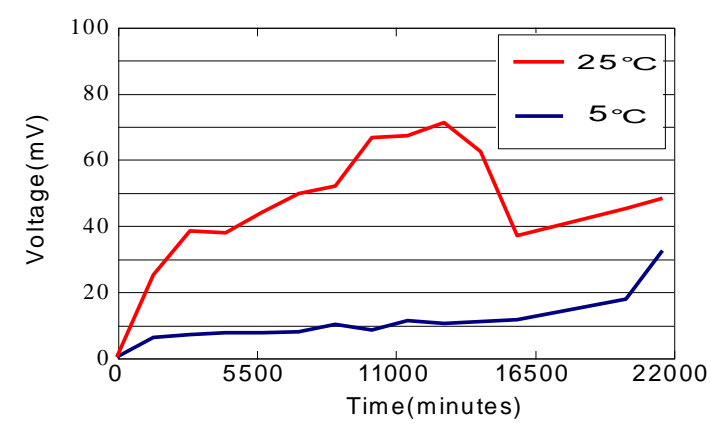

Fig. 5. Effect of temperature on voltage generation

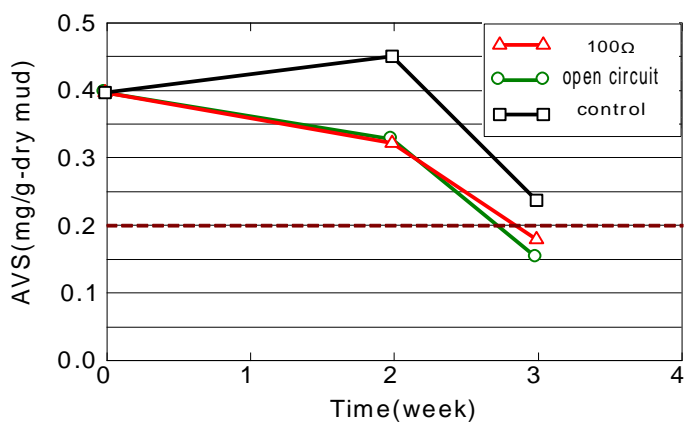

Fig. 6. Variation of AVS with time in different circuit conditions

in all type of sediments. But the black, yellow sediments collected from sea were reached at the safe limit for the benthos living in the sediments. The river sediment which is indicated as sample 4 in Fig.7 showed lower value of AVS is probably due to the size of the sediment. It was observed that the river sediment was sandy with bigger particles which helped to store the oxygen inside the particles. The anaerobic bacteria which are engaged in AVS generation can not sustain in the aerobic condition. The safe limit of AVS for the benthos which are living in the sediments are $0.2 \mathrm{mg} / \mathrm{g}$ dry mud can be achieved by using the microbial fuel cell designed by using carbon fiber. In this way, geo-environmental condition can be improved easily.

According to the United Nations, $25 \%$ of the total population in the world do not have electricity in this time. The development of the human and society largely depends on the availability of electricity, however, the scarcity of electricity is a major problems to the huge populations in the world. So we need to find some green and safe source of electricity without destroying the food products such as corn and soybean to generate biodiesel or bioethanol on the background that millions of people do not get food every day in the world. Again, due to the industrial development in many developing countries, soil pollution, sediment pollution has become a severe problem. Even in the developed countries the tidal flat mud contamination

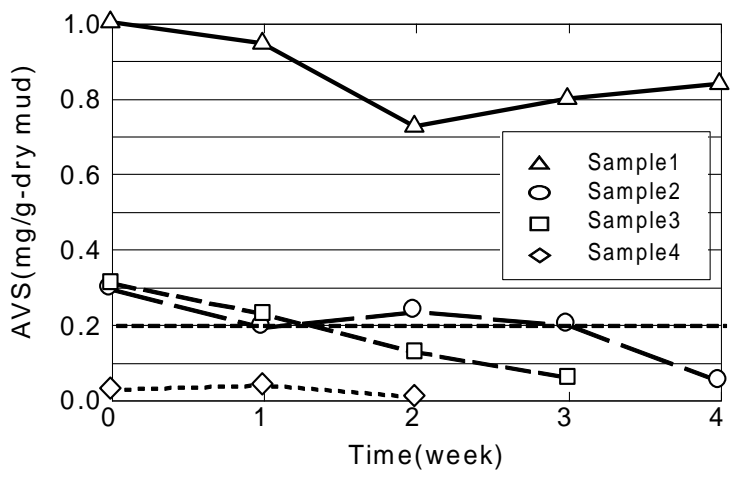

Fig.7. Variation of AVS with time in different samples

due to high value of AVS is a serious problem and many living creatures are in extinction condition. It is difficult to improve the geo-environmental condition in the tidal flat areas due to its complex natures. The proposed design of microbial fuel cell can give some hope to the people who are living in the dark to get some bio-electricity and at the same time can be a solution of contaminated sediment improvement in terms of geo-environment.

\section{CONCLUSIONS}

The following conclusions have been drawn from this study:

1) The variation of acid volatile sulfide value was observed and decreased about $0.2 \mathrm{mg} / \mathrm{g}$ dry mud indicated the improvement of the geo-environment for the marine sediments after using the microbial fuel cell technology in the contaminated sediments. By observing the different circuit conditions, it was found that the rate of AVS decrease was faster when a complete circuit was established however the AVS reduction was slowest when there was no circuit was placed in the same type of contaminated sediment.

2) Higher temperature is better for enhanced voltage generation because the bacterial activities enhanced with the enhancement of the temperature consequently increased the voltage generation.

3) The SMFCs with two anodes was about twice as high as that with one anode regarding bio-electricity generation.

4) So, designed SMFCs can both generate bio-electricity and improve the geo-environmental condition of the marine sediment. 


\section{REFERENCES}

1) Allen RM and Bennetto HP (1993) Microbial Fuel cells. Electricity production from carbohydrates. Journal of Applied Biochemistry and Biotechnology 39: 27-40.

2) Bennetto HP. (1984) Microbial fuel cells. In: Life chemistry reports. London: Harwood Academic; 365-453.

3) Benetto HP (1990). Electricity generation by microorganisms. Biotechnology Education, 1(4): 163-168.

4) Baeta-HallL S, Anselmo ML, Rosa AM (2005) Bio-degradation of olive oil husks in composting aerated piles. Bioresource Technology 96: 69-78.

5) Habermann W, and Pommer E-H. (1991) Biological Fuel Cells with sulphide storage capacity. Journal of Applied Microbial Biotechnology 35:128-133.

6) Hong S W, Chang I, Choi Y and Chung T. (2009) Experimental evaluation of influential factors for electricity harvesting from sediment using microbial fuel cell. Bioresource Technology 100: 3029-3035.

7) Logan BE and Regan JM (2006). Electricity-Producing Bacterial Communities in Microbial Fuel Cells. Trends Microbiology 14 :512-518.

8) Logan BE (2007) .Microbial Fuel Cell. Wiley-interscience, A John Wiley \& Sons, Inc., Publication.

9) Moqsud M A, Omine K, (2010) Bioelectricity generation by using organic waste in Bangladesh. Proceedings of the international conference on environmental aspects of Bangladesh, Kitakyushu, Japan, 122-126.

10) Moqsud M.A., Omine,K., Yasufuku, N.,Hyodo,M and Nakata, Y. (2013). Microbial fuel cell for bioelectricity generation from organic waste. Waste Management. 33: 2465-2469.
11) Moqsud M.A., Omine, K., Yasufuku, N., Bushra, Q.S., Hyodo, M., and Nakata,Y. (2014). Bioelectricity from kitchen and bamboo waste in a microbial fuel cell. Waste Management and Research. Vol. 32 (2) 124-130.

12) Omine K, Yasufuku N and Kanegae T. (2009) Development of compost type microbial fuel cell with anaerobic biodegradation. The $2^{\text {nd }}$ Microbial fuel cell conference at Gwangju Institute of science and technology (GIST), Korea.

13) Park, D.H and Zeikus, G. (2003). Improved fuel cell and electrode designs for the producing electricity from microbial degradation. Biotechnology anf Bioengineering, 81:348-355.

14) Rabey, K., Boon, N., Siciliano, S. D., Verhaege, M. and Verstrate, W. (2004). Biofuel cells select for microbial consortia that self-mediate electron transfer. Applied Environmental Microbiology, 70: 5373-5382.

15) Spiegel RJ, Preston JL. 2003. Technical assessment of fuel cell operation on anaerobic digester gas at the Yonkers wastewater treatment plant. Waste management 23:709-717.

16) Stirling, J.L., Bennetto, H.P., Delaney, G.M., Mason, J.R., Roller, S.B., Tanaka, K., Thurston, C.F., 1983. Microbial fuel cells. Biochemical society of transaction. 11 (4), 451-453.

17) Suzuki, S., Karube, I., Matsunaga, T., 1978. Application of a biochemical fuel cell to wastewater. Biotechnology and Bioengineering symposium.8: 501-511.

18) Tsujimura, S., Tatsumi, H., Ogawa, J., Shimizu, S., Kano, K., Ikeda, T., 2001. Bioelectrocatalytic reduction of dioxygen to water at neutral $\mathrm{pH}$ azinobis as an electron transfer mediator. Journal of Electroanalytical chemistry 34, $67-75$. 